\title{
Isoorientin induces the apoptosis and cell cycle arrest of A549 human lung cancer cells via the ROS-regulated MAPK, STAT3 and NF-kB signaling pathways
}

\author{
WAN-TING XU ${ }^{1 *}$, GUI-NAN SHEN ${ }^{1 *}$, TIAN-ZHU LI $^{2 *}$, YU ZHANG $^{1}$, TONG ZHANG $^{1}$, \\ HUI XUE ${ }^{1}$, WEN-BO ZUO ${ }^{1}$, YAN-NAN LI ${ }^{1}$, DONG-JIE ZHANG ${ }^{3,4}$ and CHENG-HAO JIN ${ }^{1,3,4}$ \\ ${ }^{1}$ Department of Biochemistry and Molecular Biology, College of Life Science and Technology, \\ Heilongjiang Bayi Agricultural University, Daqing, Heilongjiang 163319; ${ }^{2}$ Molecular Medicine Research Center, \\ School of Basic Medical Science, Chifeng University, Chifeng, Inner Mongolia Autonomous Region 024000; \\ ${ }^{3}$ Department of Food Science and Engineering, College of Food Science, Heilongjiang Bayi Agricultural University; \\ ${ }^{4}$ National Coarse Cereals Engineering Research Center, Daqing, Heilongjiang 163319, P.R. China
}

Received July 24, 2019; Accepted May 5, 2020

DOI: $10.3892 /$ ijo.2020.5079

\begin{abstract}
Isoorientin (ISO) is a naturally occurring C-glycosyl flavone that has various pharmacological properties, such as anti-bacterial and anti-inflammatory effects. However, its underlying molecular mechanisms in human lung cancer cells remain unknown. In the present study, the effects of ISO on the induction of apoptosis and relative molecular mechanisms in A549 human lung cancer cells were investigated. The results of Cell Counting Kit-8 assay (CCK-8) indicated that ISO exerted significant cytotoxic effects on 3 lung cancer cell lines, but had no obvious side-effects on normal cells. Moreover, flow cytometry and western blot analysis revealed that ISO induced mitochondrial-dependent apoptosis by reducing mitochondrial membrane potential. ISO also increased the expression levels of Bax, cleaved-caspase-3 (cle-cas-3) and poly(ADP-ribose) polymerase (PARP; cle-PARP), and decreased the expression levels of Bcl-2 in A549 cells. Furthermore, ISO induced $\mathrm{G} 2 / \mathrm{M}$ cell cycle arrest by decreasing the expression levels of
\end{abstract}

Correspondence to: Professor Cheng-Hao Jin, Department of Biochemistry and Molecular Biology, College of Life Science and Technology, Heilongjiang Bayi Agricultural University, 5 Xinfa Street, Daqing, Heilongjiang 163319, P.R. China

E-mail: jinchenghao3727@qq.com

Professor Dong-Jie Zhang, Department of Food Science and Engineering, College of Food Science, Heilongjiang Bayi Agricultural University, 5 Xinfa Street, Daqing, Heilongjiang 163319, P.R. China

E-mail: 2633204897@qq.com

*Contributed equally

Key words: isoorientin, lung cancer, apoptosis, cell cycle arrest, mitogen-activated protein kinase, signal transducer and activator of transcription 3, nuclear factor- $\kappa \mathrm{B}$ signaling pathway cyclin B1 and CDK1/2, and increasing the expression levels of p21 and p27 in A549 cells. As the duration of ISO treatment increased, intracellular reactive oxygen species (ROS) levels in A549 cells also increased. However, pre-treatment of the cells with the ROS scavenger, N-acetylcysteine (NAC), inhibited ISO-induced apoptosis. In addition, ISO increased the expression levels of p-p38, p-JNK and I $\mathrm{B}$ - $\alpha$; and decreased the expression levels of $\mathrm{p}$-extracellular signal-regulated kinase (ERK), p-signal transducer and activator of transcription

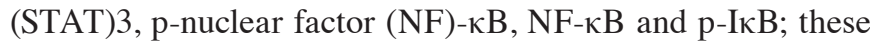
effects were induced by mitogen-activated protein kinase (MAPK) inhibitors and blocked by NAC. Taken together, the results of the present study indicate that ISO induces the apoptosis of A549 lung cancer cells via the ROS-mediated MAPK/STAT3/NF- $\mathrm{B}$ signaling pathway, and thus may be a potential drug for use in the treatment of lung cancer.

\section{Introduction}

Lung cancer remains the most prevalent malignant disease and leading cause of mortality worldwide (1). Treatment for the majority of patients with lung cancer includes surgery, chemotherapy, radiation therapy, or a combination of these treatments. Among these, chemotherapy is an effective treatment strategy for lung cancer, which can improve the overall survival rate of patients following surgery. However, side-effects such as nausea, vomiting and drug resistance often limit the use of chemotherapeutic agents (2). Among the chemotherapeutic drugs, naturally occurring flavonoids, such as baicalin, liquiritin, hesperetin and quercetin have garnered substantial interest due to their potential effects on cancer cells and lower toxicity on normal cells (3-6).

Several studies have demonstrated that reactive oxygen species (ROS) are associated with a variety of cellular processes, such as transcription factor activation, cell proliferation and apoptosis (7). The generation of intracellular ROS is an important source of mitochondrial electron transport chains. The excessive generation of intracellular ROS reduces 
mitochondrial membrane potential (MMP), leading to apoptosis (8). Moreover, the ROS-mediated mitogen-activated protein kinase (MAPK) pathway is closely associated with cell proliferation, differentiation and apoptosis. Among MAPK families, there is ample evidence that p38/MAPK, c-Jun $\mathrm{N}$-terminal kinases (JNKs) and extracellular signal-regulated kinases (ERKs) are involved on cancer initiation and progression (9). In addition, the ROS-mediated signal transducer and activator of transcription 3 (STAT3) and nuclear factor- $\kappa \mathrm{B}$ $(\mathrm{NF}-\kappa \mathrm{B})$ pathways play an important role in cancer progression (10-13). Increasing evidence has suggested that ROS induce cell apoptosis by activating the MAPK, STAT3 and $\mathrm{NF}-\kappa \mathrm{B}$ signaling pathways in cancer cells $(14,15)$.

Isoorientin (3',4',5,7-tetrahydroxy-6-C-glucopyranosyl flavone, ISO) is a well characterized naturally occurring flavonoid with biological properties representative of this group of compounds. It has been extracted from several plant species, including Patrinia, Crataegus pentagyna and Drosophyllum lusitanicum (16-18) and has anti-bacterial and anti-inflammatory activities. It has been demonstrated that ISO inhibits the rate of protein synthesis of Salmonella typhimurium, alters the permeability of the cell membrane of the bacteria, and eventually causes the leakage of nucleic acids and electrolytes; it also inhibits the proliferation of bacteria, thereby exerting antibacterial effects (19). In addition, ISO attenuates neuroinflammation by inhibiting the ROS-related MAPK/NF- $\kappa \mathrm{B}$ signaling pathway, thereby exerting anti-inflammatory effects $(20,21)$. Furthermore, ISO has been shown to induce apoptosis and cell cycle arrest of HT-29 colorectal adenocarcinoma cells (22). However, the effects of ISO-induced apoptosis on human lung cancer cells remain unknown.

The present study evaluated the anticancer effects of ISO on human lung cancer cells (A549, NCI-H23 and NCI-H460). In addition, ISO-induced apoptosis through the ROS-mediated MAPK, STAT3 and NF- $\mathrm{BB}$ signaling pathways in A549 cells was evaluated.

\section{Materials and methods}

Cell lines and cell culture. The human lung cancer cell lines A549, NCI-H23 and NCI-H460 cells, were obtained from the American Type Culture Collection (ATCC) and maintained in Dulbecco's modified Eagle's medium (DMEM; Gibco; Thermo Fisher Scientific, Inc.). Normal lung IMR-90 and normal stomach GES-1 cells were obtained from ATCC and Saiqi Biotech Co., Ltd., and maintained in DMEM (Gibco; Thermo Fisher Scientific, Inc.). All cells were supplemented with heat-inactivated fetal bovine serum (FBS; Gibco; Thermo Fisher Scientific, Inc.), $100 \mu \mathrm{g} / \mathrm{ml}$ streptomycin (Gibco; Thermo Fisher Scientific, Inc.) and $100 \mathrm{U} / \mathrm{ml}$ penicillin (Gibco; Thermo Fisher Scientific, Inc.). The cells were then cultured at $37^{\circ} \mathrm{C}$ in a $5 \% \mathrm{CO}_{2}$ atmosphere.

Cell viability assay. The cytotoxic effects of ISO treatment on lung cancer cells (A549, NCI-H23 and NCI-H460) and the side-effects of ISO (purity $\geq 99 \%$; Chengdu Herbpurify Co., Ltd.) on normal cells (IMR-90 and GES-1) were assessed using the Cell Counting Kit-8 (CCK-8) assay. Briefly, cells were seeded in 96-well culture plates at a density of $1 \times 10^{4}$ cells per well and incubated for $24 \mathrm{~h}$ at $37^{\circ} \mathrm{C}$.
5-FU, as the one of the first anticancer drug ued, inhibits thymidine nucleotide synthetase, blocks the conversion of deoxypyrimidine nucleotides into thymidine nucleus and interferes with DNA synthesis. In addition, cisplatin can bind to DNA and causes cross-linking, thereby destroying the function of DNA and inhibiting cell mitosis. It is a potent broad-spectrum anticancer drug $(23,24)$. Thus, in the present study, 5-FU and cisplatin were selected as positive control drugs. The lung cancer cells and normal cells were treated with 5-FU (Medchem Express), cisplatin (Solarbio Science $\&$ Technology Co., Ltd.) and ISO at various concentrations $(20,40,60,80$ and $100 \mu \mathrm{M})$ for $24 \mathrm{~h}$ or different periods of time $\left(3,6,12,24\right.$ and $36 \mathrm{~h}$ ) at $46.81 \mu \mathrm{M}$ (the $\mathrm{IC}_{50}$ value of A549 cells). Subsequently, $10 \mu 1$ CCK-8 solution were added to each well followed by incubation for $3 \mathrm{~h}$ at $37^{\circ} \mathrm{C}$. The absorbance values were measured using a microplate reader (BioTek Instruments Inc.) at $450 \mathrm{~nm}$ and the experiments were performed 3 times with 16 wells per experiment. Finally, the obtained OD values were analyzed using GraphPad Prism software, and the corresponding $\mathrm{IC}_{50}$ values were then obtained using GraphPad Prism software.

Analysis of cell apoptosis. The effects of ISO on cell apoptosis were measured using the Apoptosis and Necrosis Assay kit and Annexin V Detection kit (Beyotime Institute of Biotechnology). The A549 cells were seeded in 6-well culture plates at a density of $1 \times 10^{5}$ per well and treated with $46.81 \mu \mathrm{M}$ ISO for different periods of time (3, 6, 12 and $24 \mathrm{~h}$ ). After the cells were collected, they were re-suspended in $100 \mu \mathrm{l}$ cell staining buffer, followed by the addition of $5 \mu 1$ Hoechst 33342 staining solution and $1.5 \mu \mathrm{l}$ propidium iodide (PI) staining solution, incubation for $10 \mathrm{~min}$ at $37^{\circ} \mathrm{C}$, and observation with a fluorescence microscope (Thermo Fisher Scientific, Inc.). The collected A549 cells were then cultured in $195 \mu \mathrm{l}$ Annexin $\mathrm{V}$ staining buffer, followed by the addition of $3 \mu \mathrm{l}$ Annexin V-FITC and $2 \mu \mathrm{l}$ PI for $10 \mathrm{~min}$. The percentages of apoptotic cells were analyzed using a flow cytometry (Beckman Coulter, Inc.).

Detection of MMP. The MMP of A549 cells was detected using the MMP Detection kit (JC-1; Beyotime Institute of Biotechnology). After the A549 cells were grown in a 6-well culture plate at a density of $1 \times 10^{5}$ cells per well, they were treated with $46.81 \mu \mathrm{M}$ ISO for different periods of time $(3,6$, 12 and $24 \mathrm{~h}$ ). The A549 cells were incubated with JC-1 working solution at $37^{\circ} \mathrm{C}$ for $20 \mathrm{~min}$. The cells were then washed twice with $1 \mathrm{X}$ JC-1 staining buffer solution. The data were analyzed by flow cytometry.

Analysis of cell cycle arrest. The cell cycle arrest of ISO-treated A549 cells was assessed by a DNA Content Quantitation assay (Solarbio Science \&Technology Co., Ltd.). Briefly, the A549 cells were treated with $46.81 \mu \mathrm{M}$ ISO for different periods of time $(3,6,12$ and $24 \mathrm{~h})$. After pre-cooling with $70 \%$ ethanol overnight, they were washed twice with phosphate-buffered saline (PBS), followed by the addition of $100 \mu \mathrm{l}$ RNase A solution and the re-suspension of cells at $37^{\circ} \mathrm{C}$ for $30 \mathrm{~min}$. Finally, $400 \mu \mathrm{l}$ PI staining solution were added, and the cells were incubated for $30 \mathrm{~min}$ at $4^{\circ} \mathrm{C}$. The data were then analyzed by flow cytometry. 

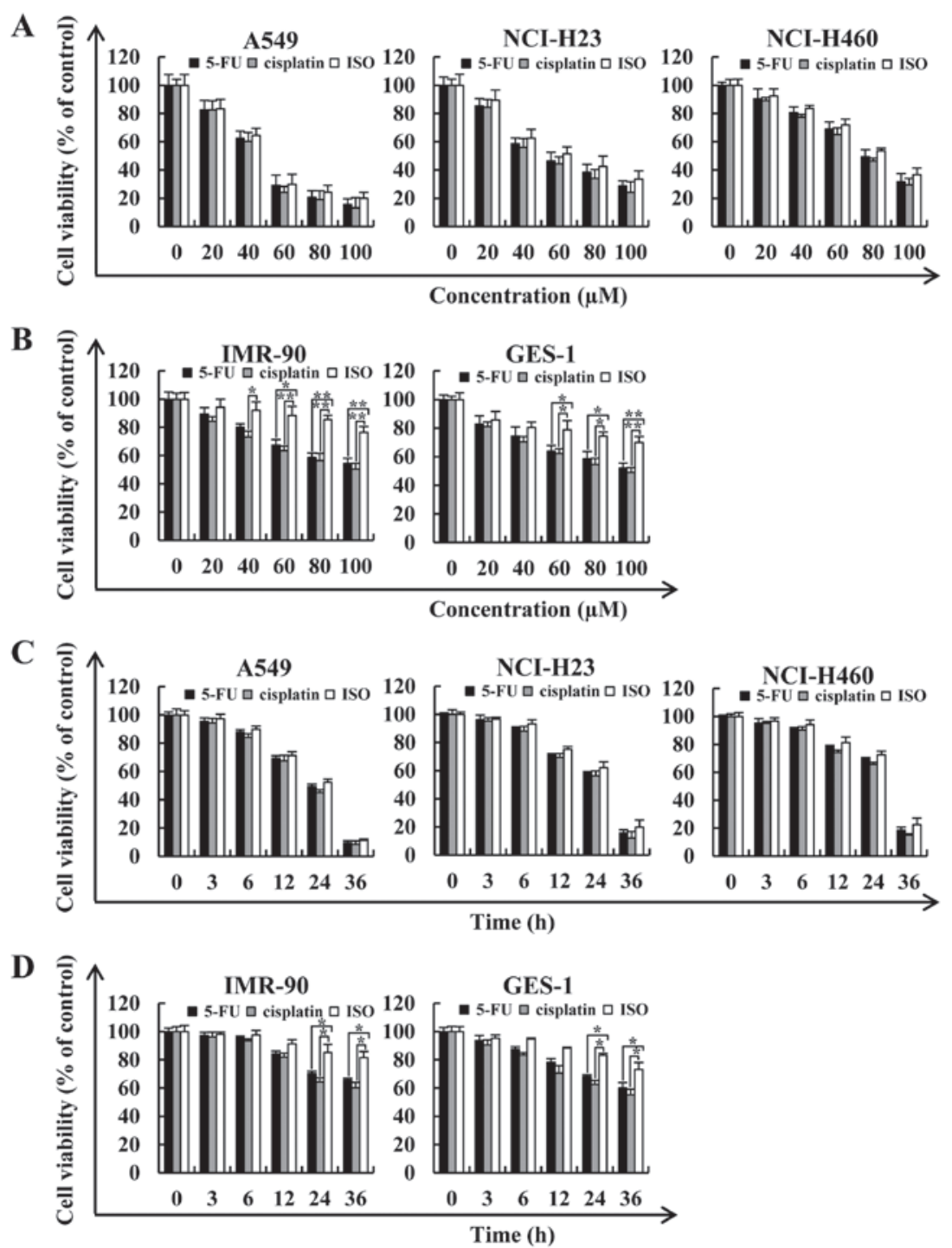

Figure 1. Cytotoxic effects of ISO on human lung cancer cells. (A) A549, NCI-H23 and NCI-H460 lung cancer cells were treated with various concentrations of 5-FU, cisplatin and ISO $(20,40,60,80$ and $100 \mu \mathrm{M})$ for $24 \mathrm{~h}$, after which their cell viabilities were determined by CCK-8 assay. (B) IMR-90 and GES-1 normal cells were treated with various concentrations of 5-FU, cisplatin and ISO $(20,40,60,80$ and $100 \mu \mathrm{M})$ for $24 \mathrm{~h}$, after which their cell viabilities were determined by CCK-8 assay. (C) A549, NCI-H23 and NCI-H460 cells were treated for different periods of time $(3,6,12,24$ and $36 \mathrm{~h})$ with the IC I0 $_{5}$ value of ISO, after which their cell viabilities were determined by CCK-8 assay. (D) IMR-90 and GES-1 cells were treated for different periods of time (3, 6, 12, 24 and $36 \mathrm{~h}$ ) with the $\mathrm{IC}_{50}$ value of ISO, after which their cell viabilities were determined by CCK- 8 assay. Data are expressed as the means $\pm \mathrm{SD}$. "P<0.05 and ${ }^{* *} \mathrm{P}<0.01$ vs. control. ISO, isoorientin.

Preparation of nuclear extracts. The Nuclear Protein Extraction kit was used to prepare the nuclear extract. The A549 cells were treated with $46.81 \mu \mathrm{M}$ ISO for different periods of time (3, 6, 12 and $24 \mathrm{~h})$, and then washed with PBS once; the cells were then centrifuged at $500 \mathrm{x}$ g for $3 \mathrm{~min}$ in room temperature. After the cells were resuspended with $80 \mu 1$ plasma protein extraction reagent, they were incubated on ice for $10 \mathrm{~min}$. The cells were then centrifuged at $12,000 \mathrm{x} \mathrm{g}$ for $10 \mathrm{~min}$ at $4^{\circ} \mathrm{C}$ and the supernatants were used as the cytosolic extract. The precipitate was then resuspended in $50 \mu \mathrm{l}$ nuclear protein extraction reagent and incubated on ice for $10 \mathrm{~min}$. The cells were then centrifuged at $12,000 \mathrm{x}$ g for $10 \mathrm{~min}$ at $4^{\circ} \mathrm{C}$. The supernatant was used as the nuclear protein.

Western blot analysis. The expression levels of relevant proteins were measured by western blot analysis. After the A549 cells were treated with $46.81 \mu \mathrm{M}$ ISO for different periods of times
(3, 6, 12 and $24 \mathrm{~h})$, the cells were collected, and protein was extracted using cell lysis buffer. For the inhibitor-treated cell samples, the A549 cells were pre-treated 30 min with $10 \mu \mathrm{M}$ MAPK inhibitors (the pharmacological inhibitor of p38, SB203580; the pharmacological inhibitor of JNK, SP600125; and the pharmacological inhibitor of ERK, FR180204; all from MedChem Express) at $37^{\circ} \mathrm{C}$ and were then treated with $46.81 \mu \mathrm{M}$ ISO for $24 \mathrm{~h}$. For $N$-acetylcysteine (NAC)-treated cell samples, the A549 cells were pre-treated $30 \mathrm{~min}$ with $10 \mu \mathrm{M}$ NAC (Sigma-Aldrich; Merck KGaA) at $37^{\circ} \mathrm{C}$ and then treated with $46.81 \mu \mathrm{M}$ ISO for $24 \mathrm{~h}$. Briefly, the cells were centrifuged at $12,000 \mathrm{x}$ g for $30 \mathrm{~min}$ at $4^{\circ} \mathrm{C}$. An equal amount of protein $(30 \mu \mathrm{g})$ was loaded onto 10-12\% SDS-PAGE gels and electro-transferred onto nitrocellulose membranes (EMD Millipore). The membranes were then blocked in 5\% skim milk in Tris-buffered saline Tween-20 (TBST) for $2 \mathrm{~h}$, followed by overnight incubation at $4^{\circ} \mathrm{C}$ with specific primary antibodies 

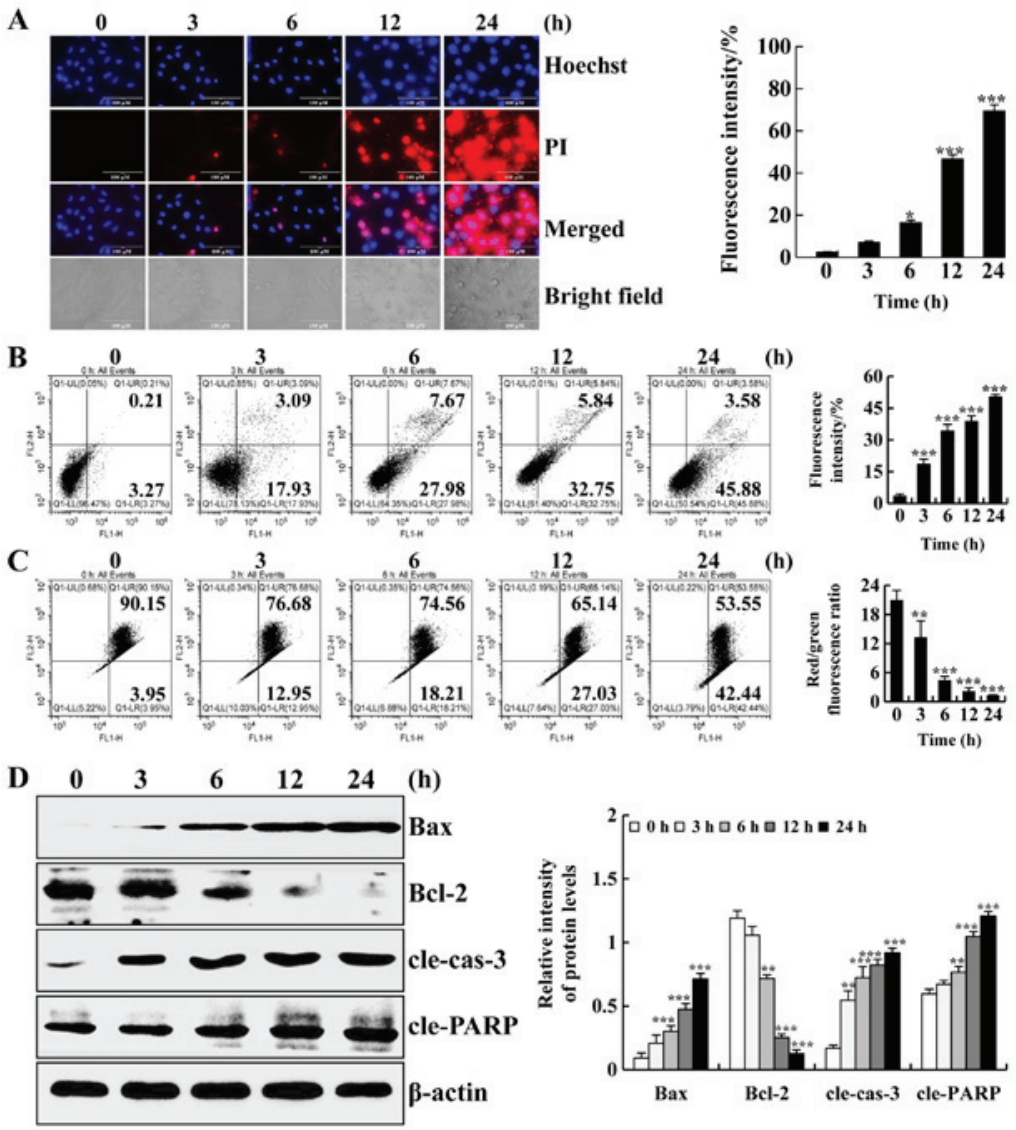

Figure 2. Apoptotic effects of ISO on A549 cells. (A) A549 cells were stained with Hoechst 33342 and PI, and the fluorescence intensities and morphology changes of cells were observed under a fluorescence microscope (original magnification, x200). (B) Percentages of apoptotic cells were detected by flow cytometry. (C) MMP was detected by flow cytometry. (D) The protein expression levels were measured by western blot analysis following treatment of A549 cells with ISO. The percentages of apoptotic cells represent the mean $\pm \mathrm{SD} ; \beta$-actin was used as the loading control. ${ }^{*} \mathrm{P}<0.05,{ }^{* * *} \mathrm{P}<0.01$ and ${ }^{* * * *} \mathrm{P}<0.001$ vs. $0 \mathrm{~h}$. ISO, isoorientin; MMP, mitochondrial membrane potential.

(from Santa Cruz Biotechnology, Inc.), against mouse monoclonal $\beta$-actin $(1: 2,500$; cat. no. sc-47778), Lamin B1 (1:2,500; cat. no. sc-374015), Bax (1:1,500; cat. no. sc-493), Bcl-2 (1:1,500; cat. no. sc-7382), cleaved-caspase-3 (cle-cas-3; 1:1,500; cat. no. sc-373730), poly(ADP) ribose polymerase (PARP)-1 (1:1,500; cat. no. sc-8007), p-p38 (1:1,500; cat. no. sc-7973), p-JNK (1:1,500; cat. no. sc-6254), JNK (1:1,500; cat. no. sc-7345), p-ERK (1:1,500; cat. no. sc-7383), p-STAT3 (1:1,500; cat. no. sc-8059), STAT3 (1:1,500; cat. no. sc-8019),

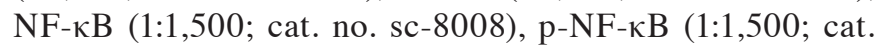
no. sc-166748), inhibitor of $\mathrm{I} \kappa \mathrm{B}-\alpha(\mathrm{I} \kappa \mathrm{B}-\alpha ; 1: 1,500$; cat. no. sc-1643), p-IкB- $\alpha$ (1:1,500; cat. no. sc-8404), cyclin B1 (1:1,500; cat. no. sc-245), CDK1/2 (1:1,500; cat. no. sc-53219), against rabbit monoclonal p38 $\alpha / \beta(1: 1,500$; cat. no. sc-7149), p27 (1:1,500; cat. no. sc-528), p21 (1:1,500; cat. no. sc-397). The membranes were then incubated with horseradish peroxidase (HRP)-conjugated secondary antibodies (i.e., HRP-conjugated AffiniPure goat anti-mouse IgG and HRP-conjugated AffiniPure goat anti-rabbit $\mathrm{IgG}$ ) for $1 \mathrm{~h}$ at room temperature. Proteins were measured using enhanced chemiluminescence kits (Bio-Rad Laboratories, Inc.). Band intensity was assessed using ImagesJ software version 1.42q.

Detection of intracellular ROS levels. Intracellular ROS levels were measured using the 2',7'-dichlorofluorescein diacetate (DCFH-DA; Beyotime Institute of Biotechnology) fluorescent probe. The cells were treated with $46.81 \mu \mathrm{M}$ ISO for different periods of time $(3,6,12$ and $24 \mathrm{~h})$. The collected cells were washed twice with PBS. The cells were then incubated with DCFH-DA for $30 \mathrm{~min}$ at $37^{\circ} \mathrm{C}$, and were again washed twice with PBS. The fluorescence intensity of DCF, which represents intracellular ROS levels, was analyzed using a flow cytometer (Beckman Coulter, Inc.) in the cell samples.

Statistical analysis. All data are presented as the means \pm standard deviation from 3 experiments. Continuous data were analyzed by one-way analysis of variance followed by Tukey's post-hoc test using SPSS software version 21.0. P-values $<0.05$ were considered to indicate statistically significant differences.

\section{Results}

ISO exerts cytotoxic effects on human lung cancer cells. To determine the effects of ISO on lung cancer cell viability, the A549, NCI-H23 and NCI-H460 cells were treated with 5-FU and ISO, and after $24 \mathrm{~h}$, cell viability was measured by CCK-8 assay. As shown in Fig. 1A, 5-FU, cisplatin and ISO exerted significant cytotoxic effects on lung cancer cells (A549, NCI-H23 and NCI-H460) in a dose-dependent manner. As human lung fibroblasts (IMR-90) are extracted from embryonic cells, their primary properties have not transformed. This can directly reflect the toxic effects to the human lungs in the 

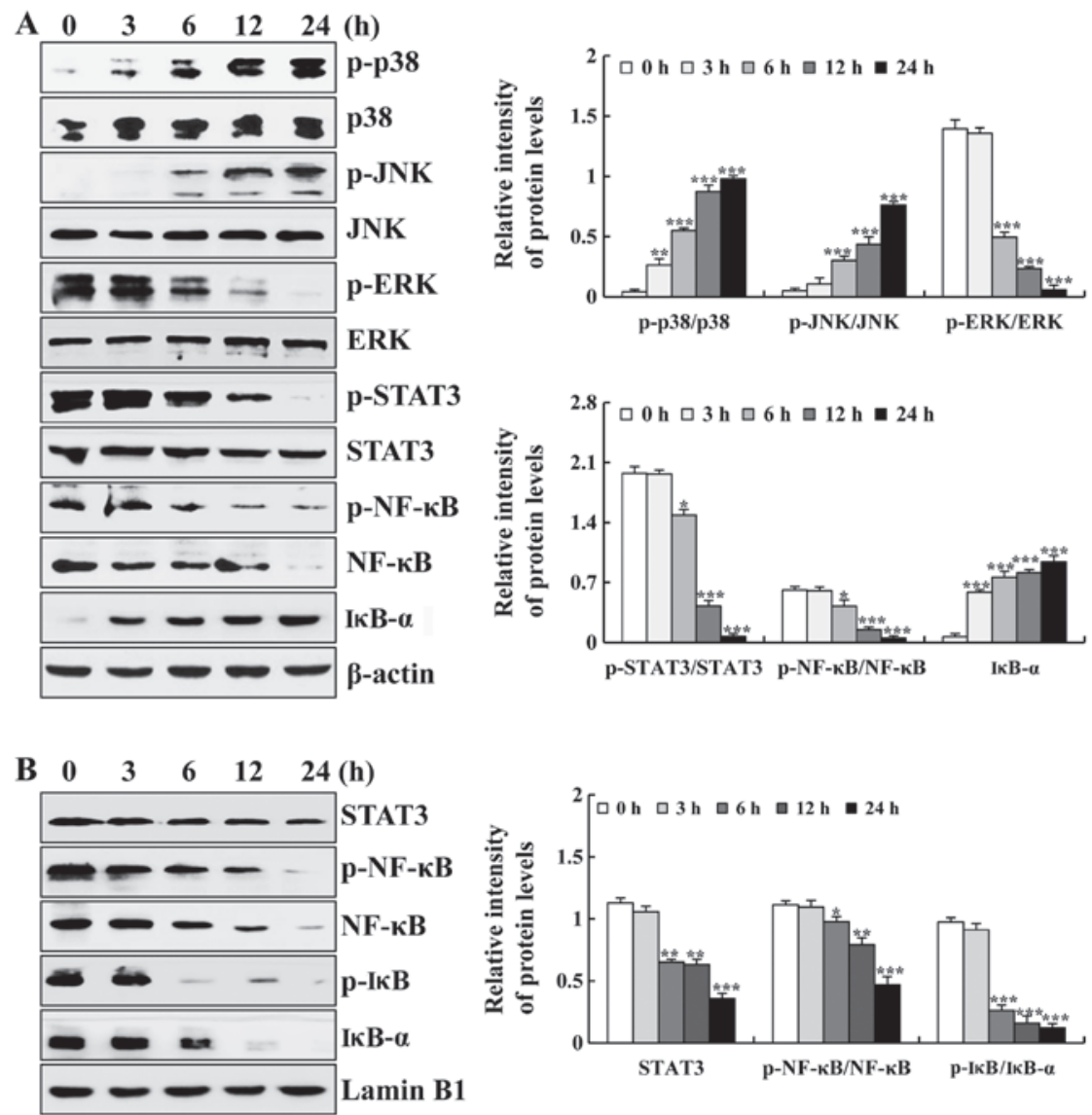

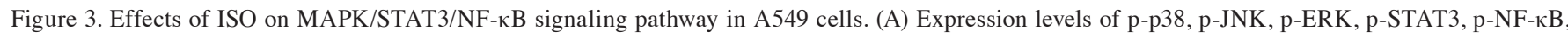

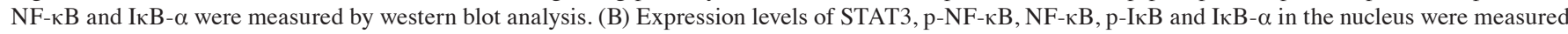
by western blot analysis. The phosphorylated proteins were quantified with corresponding total proteins. $\beta$-actin and Lamin B1 were used as the loading controls. ${ }^{*} \mathrm{P}<0.05,{ }^{* *} \mathrm{P}<0.01$ and ${ }^{* * *} \mathrm{P}<0.001$ vs. 0 h. ISO, isoorientin.

toxicity experiment of the compounds. Furthermore, GES-1 cells are human gastric mucosal epithelial cells. The drug used in this experiment is a compound extracted from Chinese herbal medicine, which is mainly digested and metabolized in the stomach. Therefore, the IMR-90 and GES-1 cells were selected for the determination of ISO cytotoxicity. Importantly, compared with 5-FU and cisplatin, following treatment with ISO, the survival rate of the human normal cells (IMR-90 and GES-1) did not evidently decrease (Fig. 1B). Among the lung cancer cells, the A549 cells were more sensitive to ISO than the NCI-H23 and NCI-H460 cells, and the half-maximal inhibitory values $\left(\mathrm{IC}_{50}\right)$ of ISO for the lung cancer cells are presented in Table I. In addition, the results of CCK-8 assay revealed that 5-FU, cisplatin and ISO exerted evident growth-inhibitory effects on the lung cancer cells and the $\mathrm{IC}_{50}$ value was reached in the $\mathrm{A} 549$ cells at $24 \mathrm{~h}$ (Fig. 1C). It was found that the concentration of ISO did not reach its $\mathrm{IC}_{50}$ value when it exceeded $100 \mu \mathrm{M}$; thus, it was considered that its $\mathrm{IC}_{50}$ value exceeds $100 \mu \mathrm{M}$. In addition, in order to ensure that normal cells and cancer cells were compared at the same level, the $\mathrm{IC}_{50}$ value of ISO for the experiments was selected based on the toxicity of normal cell time gradients. As shown in Fig. 1D, compared with 5-FU and cisplatin, treatment with $46.81 \mu \mathrm{M}$ ISO for $24 \mathrm{~h}$ exerted no obvious effects on normal cells (Fig. 1D). Based on the results shown in Fig. 1C and D, it was found that the cytotoxic effects of ISO on lung cancer cells were similar to those of 5-FU and cisplatin; however, ISO exerted less side-effects than 5-FU and cisplatin on normal cells. In addition, when the cells were treated with $46.81 \mu \mathrm{M}$ ISO for different periods of time $(3,6,12,24$ and $36 \mathrm{~h})$, the cells begun to undergo apoptosis and gradually die. In particular, when the treatment time reached $36 \mathrm{~h}$, a large number of cells were apoptotic and exfoliated from the plate, rendering subsequent experiments impossible. Thus, subsequent experiments were conducted at different time points $(3,6,12$ and $24 \mathrm{~h})$.

ISO induces the apoptosis of A549 cells. To verify the effects of ISO on lung cancer cell apoptosis, the A549 cells were processed with ISO for different periods of time $(3,6,12$ and $24 \mathrm{~h}$ ), and the fluorescence intensity was detected with a fluorescence microscope. As shown in Fig. 2A, the fluorescence intensity of Hoechst 33342 and PI and the degree of cell shrinkage were increased. Next, we detected the apoptotic effects of ISO in A549 cells by flow cytometry. As shown in Fig. 2B, the ratio of apoptotic cells was increased. In addition, early apoptotic cells were accompanied by changes in MMP. As shown in Fig. 2C, the ratio of red to green fluorescence was significantly decreased, indicating that ISO reduced MMP in a time-dependent manner. Consistently, to further investigate the molecular mechanisms through which ISO induced the apoptosis of A549 cells, the expression levels of apoptosis-related proteins were examined by western blot analysis. As shown in 
$\mathbf{A}$

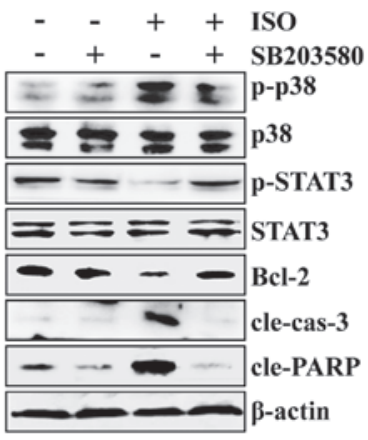

B

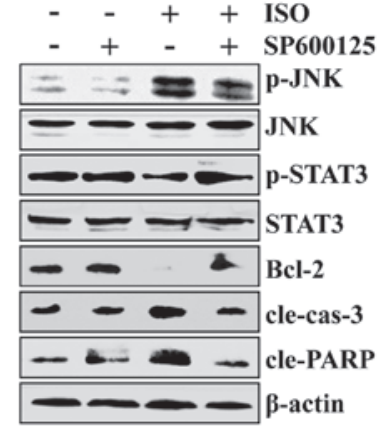

C

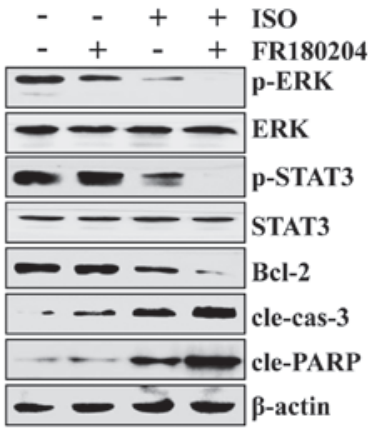

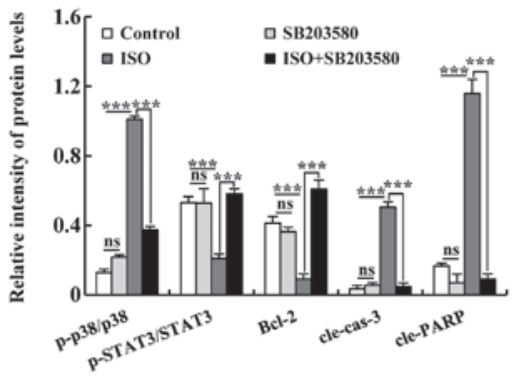
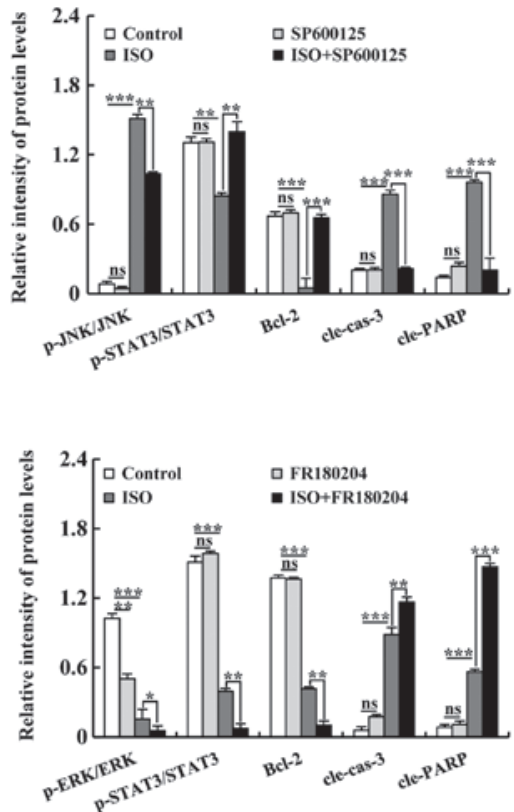

Figure 4. Effects of ISO on the MAPK and STAT3 signaling pathways in A549 cells. (A) Expression levels of p-p38, p-STAT3, Bcl-2, cle-cas-3 and cle-PARP proteins in ISO-treated and p38 inhibitor-treated A549 cells. (B) Expression levels of p-JNK, p-STAT3, Bcl-2, cle-cas-3 and cle-PARP proteins in ISO-treated and JNK inhibitor-treated A549 cells. (C) Expression levels of p-ERK, p-STAT3, Bcl-2, cle-cas-3 and cle-PARP proteins in ISO-treated and ERK inhibitor-treated A549 cells. The phosphorylated proteins were quantified with corresponding total proteins. $\beta$-actin was used as the loading control. " $\mathrm{P}<0.05$, ${ }^{* *} \mathrm{P}<0.01$ and ${ }^{* * *} \mathrm{P}<0.001$ vs. ISO + MAPK inhibition. ns, not significant; ISO, isoorientin.

Fig. 2D, the protein expression levels of Bax, cleaved caspase-3 (cle-cas-3) and cleaved PARP (cle-PARP) were increased. Furthermore, the protein expression levels of Bcl-2 were decreased. Thus, these results demonstrated that ISO induced apoptosis via a mitochondrial-dependent pathway in A549 cells.

ISO induces apoptosis through the MAPK, STAT3 and $N F-\kappa B$ signaling pathways in A549 cells. To further determine the molecular mechanisms responsible for the ISO-induced apoptosis of A549 cells, the related protein expression levels of MAPK, STAT3 and NF- $\mathrm{BB}$ were measured by western blot analysis. As shown in Fig. 3A, the protein expression levels of p-p38, p-JNK and I $\mathrm{B}$ - $\alpha$ were increased, whereas the protein expression levels of p-ERK, p-STAT3, p-NF- $\kappa$ B and NF- $\kappa$ B were decreased. As a nuclear transcription factor, the nuclear translocation of proteins (STAT3, p-NF- $\kappa$ B, NF- $\kappa \mathrm{B}, \mathrm{p}-\mathrm{I} \kappa \mathrm{B}$ and $\mathrm{I} \kappa \mathrm{B}-\alpha$ ) is required for their function. As shown in Fig. 3B, the nuclear protein expression levels of STAT3, p-NF- $\mathrm{B}, \mathrm{NF}-\kappa \mathrm{B}, \mathrm{p}-\mathrm{I} \kappa \mathrm{B}$ and
I $\mathrm{B}-\alpha$ were decreased. In addition, to verify the effects of MAPK and STAT3 signaling pathways on the ISO-induced apoptosis of human lung cancer cells, the A549 lung cancer cells were pre-treated with $10 \mu \mathrm{M} \mathrm{SB} 203580$ (a pharmacological inhibitor of p38), $10 \mu \mathrm{M}$ SP600125 (a pharmacological inhibitor of JNK) and $10 \mu \mathrm{M}$ FR180204 (a pharmacological inhibitor of ERK), and the protein expression levels of the MAPKs and STAT3 were measured by western blot analysis. As shown in Fig. 4A and B, following pre-treatment with SB203580 or SP600125 alone, no significant differences were observed between the SB203580 group or SP600125 group and the control group. Compared with the control group, the protein expression levels of p-STAT3 and Bcl-2 were decreased, while the protein expression levels of $\mathrm{p}-\mathrm{p} 38$, p-JNK, cle-cas-3 and cle-PARP were increased in the ISO group. Moreover, following pre-treatment with SB203580 or SP600125, compared with the ISO group, the protein expression levels of p-STAT3 and Bcl-2 were increased, while the protein expression levels of p-p38, p-JNK, cle-cas-3 and cle-PARP were decreased in the ISO + SB203580 group 

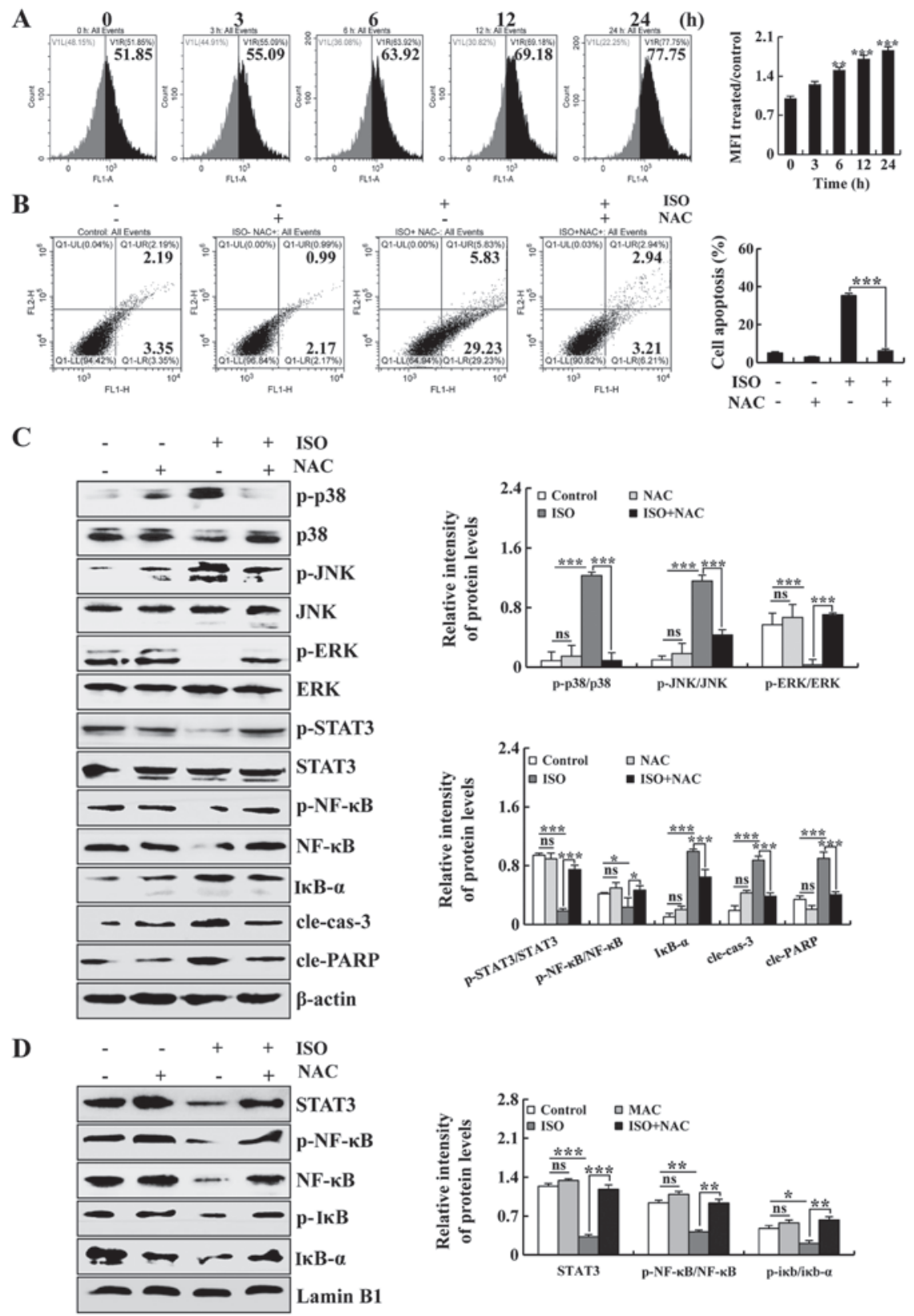

Figure 5. Promoting effects of ISO on ROS generation and the induction of apoptosis of A549 cells. (A) A549 cells were treated with ISO, and the intracellular ROS levels were measured by flow cytometry. (B) A549 cells were treated with NAC and ISO. The percentages of apoptotic cells were then measured by flow cytometry. (C) A549 cells were treated with ISO and NAC, after which the expression levels of MAPKs, STAT3, NF- $\kappa$ B, cle-cas-3 and cle-PARP were detected

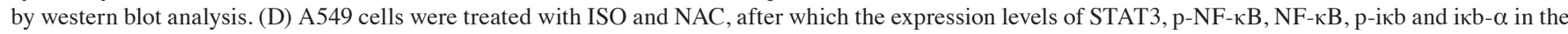
nucleus were detected by western blot analysis. The phosphorylated proteins were quantified with corresponding total proteins. $\beta$-actin and Lamin B1 was used as the loading controls. ${ }^{*} \mathrm{P}<0.05,{ }^{* *} \mathrm{P}<0.01$ and ${ }^{* * *} \mathrm{P}<0.001$ vs. the NAC + ISO group. ns, not significant; ISO, isoorientin.

or ISO + SP600125 group. As shown in Fig. 4C, following pre-treatment with FR180204 alone, the expression level of p-ERK was decreased and that of the other 4 proteins exhibit no significant difference between the FR180204 group and the control group. Briefly, compared with the control group, the protein expression levels of p-ERK, p-STAT3 and Bcl-2 were decreased, while the protein expression levels of cle-cas-3 and cle-PARP were increased in the ISO group. Furthermore, following pre-treatment with FR180204, compared with the ISO group, the protein expression levels of p-ERK, p-STAT3 and Bcl-2 were decreased, while the protein expression levels of cle-cas- 3 and cle-PARP were increased in the ISO + FR180204 group. Taken together, these results indicated that the MAPK/STAT3/NF- $\mathrm{BB}$ signaling pathways were associated with the ISO-induced apoptosis of A549 cells.

ISO-induced cell apoptosis is dependent on the ROS-mediated MAPK/STAT3/NF- $\mathrm{KB}$ signaling pathway in A549 cells. To investigate whether ROS are associated with the ISO-induced apoptosis of A549 cells, intracellular ROS levels were detected by flow cytometry. As shown in Fig. 5A, following treatment with ISO, the intracellular ROS levels were significantly increased. In addition, the apoptosis of A549 cells was significantly decreased following pre-treatment with NAC (Fig. 5B). To further investigate whether ISO induces cell apoptosis 


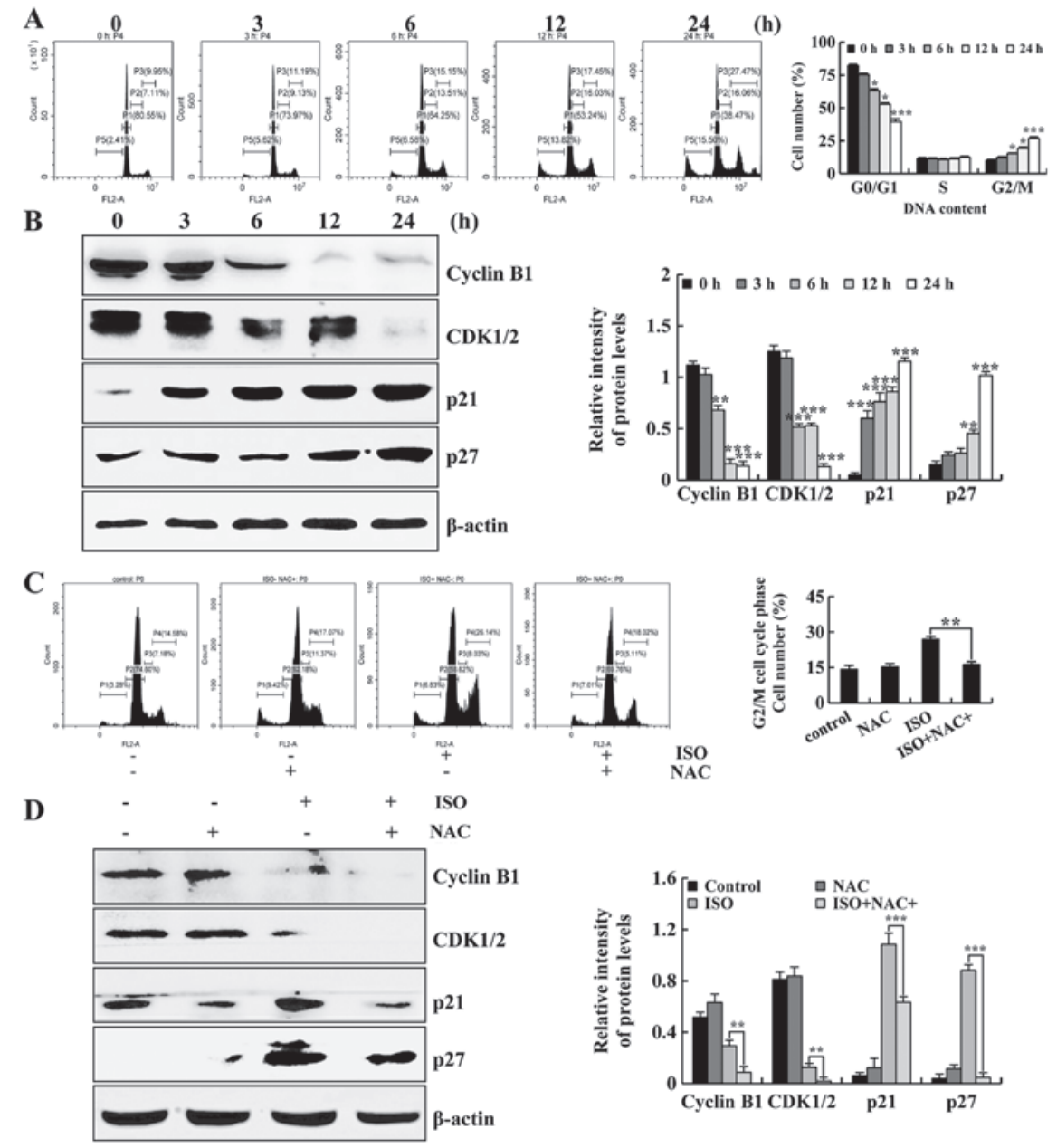

Figure 6. Effects of ISO on the cell cycle of A549 cells. (A) The percentages of cell cycle were detected by flow cytometry. (B) Expression levels of G2/M cell cycle-related proteins cyclin B1, CDK1/2, p21 and p27 were examined by western blot analysis following treatment with ISO. (C) A549 cells were treated with NAC and ISO, and the percentages of cell cycle were then detected by flow cytometry. (D) A549 cells were treated with ISO and NAC, after which the expression levels of cyclin $\mathrm{B} 1, \mathrm{CDK} 1 / 2$, p21, and $\mathrm{p} 27$ were detected by western blot analysis. $\beta$-actin was used as the loading controls. ${ }^{*} \mathrm{P}<0.05$, ${ }^{* *} \mathrm{P}<0.01$ and ${ }_{* * * *} \mathrm{P}<0.001$ vs. $0 \mathrm{~h}$ or the NAC + ISO group. ISO, isoorientin.

via the ROS-mediated MAPK, STAT3 and NF- $\mathrm{B}$ signaling pathways, the A549 cells were pre-treated with NAC, and the protein expression levels of MAPK, STAT3, p-NF- $\kappa B$ and NF- $\kappa \mathrm{B}$, as well as the nuclear protein expression levels

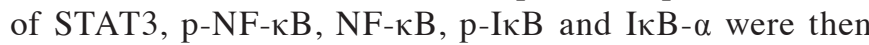
detected. As shown in Fig. 5C, following pre-treatment with NAC, no significant differences were observed between the NAC group and the control group. Compared with the control group, the expression levels of p-p38, p-JNK, IкB- $\alpha$, cle-cas-3 and cle-PARP were significantly upregulated, while the expression levels of p-ERK, p-STAT3, p-NF- $\kappa \mathrm{B}$ and NF- $\kappa \mathrm{B}$ were downregulated in the ISO group. Furthermore, following pre-treatment with NAC, compared with the ISO group, the expression levels of p-p38, p-JNK, IкB- $\alpha$, cle-cas- 3 and cle-PARP were significantly downregulated, while the expression levels of p-ERK, p-STAT3, p-NF- $\kappa$ B and NF- $\kappa \mathrm{B}$ were upregulated in the ISO + NAC group. In addition, as shown in Fig. 5D, following pre-treatment with NAC, no significant differences were observed between the NAC group and the control group. Compared with the control group, the nuclear protein expression levels of STAT3, p-NF- $\mathrm{kB}$ and NF- $\kappa \mathrm{B}$ were significantly decreased in the ISO group. In brief, following pre-treatment with NAC, compared with the ISO group, the nuclear protein expression levels of STAT3, p-NF- $\kappa \mathrm{B}, \mathrm{NF}-\kappa \mathrm{B}$, $\mathrm{p}-\mathrm{I} \kappa \mathrm{B}$ and I $\kappa \mathrm{B}-\alpha$ were increased in the ISO + NAC group.

ISO leads to the G2/M cell cycle arrest of the A549 cells. To determine the effects of ISO on lung cancer cell cycle arrest, the A549 cells were treated with ISO for different periods of time (3, 6, 12 and $24 \mathrm{~h}$ ) followed by detection with flow cytometry. As shown in Fig. 6A, the population of A549 cells in the G2/M phase was markedly increased. Subsequently, the expression of G2/M cell cycle-related proteins was detected by western blot analysis. It was found that the protein expression levels of cyclin B1 and CDK1/2 were decreased. Moreover, the protein expression levels of p21 and p27 were increased. These data indicated that ISO caused the G2/M cell cycle arrest of the A549 cells. Furthermore, the cells were pre-treated with NAC, and the population of A549 cells in the G2/M phase was measured by flow cytometry. As shown in Fig. 6C, compared with the ISO group, the population of $\mathrm{G} 2 / \mathrm{M}$ phase cells was significantly decreased in the ISO + NAC group. Moreover, NAC significantly downregulated the expression levels of cyclin $\mathrm{B} 1$ and CDK1/2, and upregulated the expression levels of p21 and p27 compared to ISO treatment alone (Fig. 6D). Taken together, these results suggested that ISO induced 


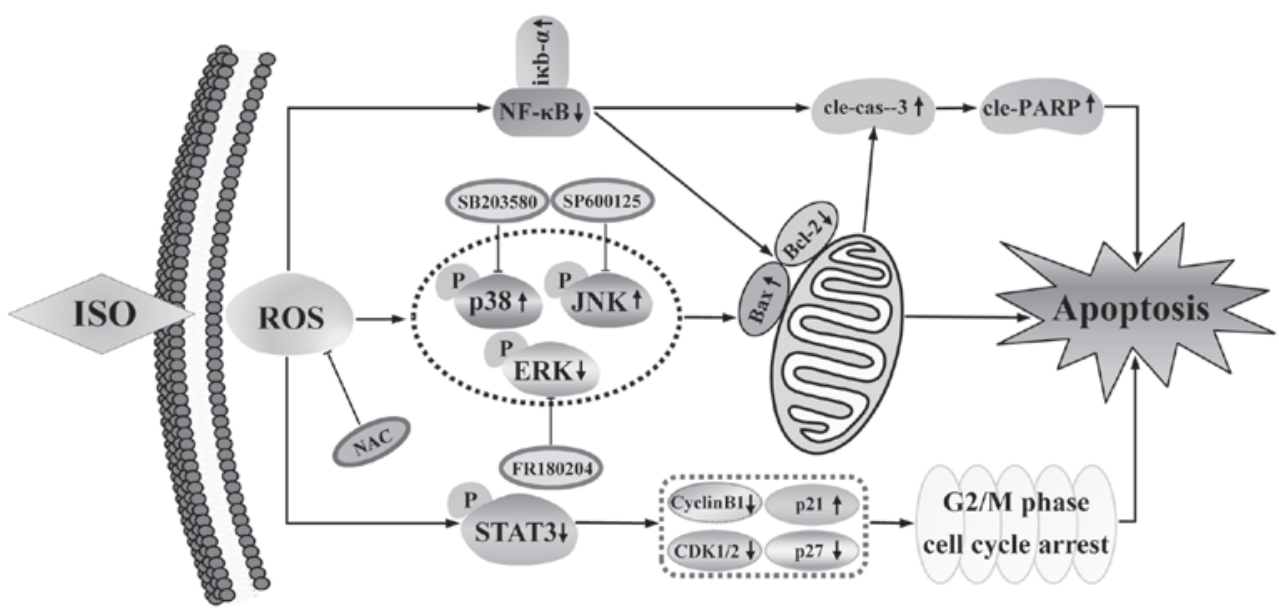

Figure 7. The underlying mechanisms of the anticancer activity of ISO on A549 human lung cancer cells. ISO, isoorientin.

Table I. $\mathrm{IC}_{50}$ values of ISO and 5-FU in lung cancer cells.

\begin{tabular}{lll}
\hline Cell line & 5 -FU $(\mu \mathrm{M})$ & ISO $(\mu \mathrm{M})$ \\
\hline A549 & $43.52 \pm 1.83$ & $46.81 \pm 2.37$ \\
NCI-H23 & $57.15 \pm 2.14$ & $63.88 \pm 1.49$ \\
NCI-H460 & $79.82 \pm 1.54$ & $81.69 \pm 1.56$ \\
\hline
\end{tabular}

The $\mathrm{IC}_{50}$ values were calculated using GraphPad Prism software.

apoptosis and G2/M cell cycle arrest via the ROS-mediated MAPKs/STAT3/NF- $\mathrm{KB}$ signaling pathways in A549 human lung cancer cells (Fig. 7).

\section{Discussion}

Traditional Chinese herbal medicine is one of the topics in the antitumor drug development arena. Certain studies have noted that herbs with anticancer effects can be separated into several compounds including flavonoids $(25,26)$. ISO, a naturally $\mathrm{C}$-glycosyl flavone, has been shown to inhibit the proliferation of HepG2 liver cancer cells, with no obvious cytotoxicity on HL-7702 normal human liver cells (27). Several studies have demonstrated that the anticancer mechanisms of ISO involve the inhibition of cancer cell proliferation, the promotion of oxidative stress, the induction of cell cycle arrest, and ultimately, in the induction of apoptosis $(22,27-34)$. However, the experimental data of the present study revealed that ISO induced ROS accumulation, apoptosis and G2/M cycle arrest in the lung cancer cells, and the present study also investigated the relevant molecular mechanisms. It was found that ROS accumulation induced by ISO activated the MAPK signaling pathway and further inhibited the STAT3 and NF- $\mathrm{\kappa B}$ signaling pathways. ISO also exerted effects on nuclear transcription factors, such as the nuclear translocation of proteins (STAT3, p-NF- $\kappa B, N F-\kappa B$ and p-IкB), finally causing the apoptosis of A549 lung cancer cells. On the other hand, ROS accumulation regulated the expression of $\mathrm{CDK}$ and cyclin, causing the G2/M phase arrest of the A549 lung cancer cells. Finally, a theoretical basis was provide for the drug design and anticancer drug development by ISO. It has previously found that the $\mathrm{IC}_{50}$ value of the HT-29 cells was $125 \mu \mathrm{M}$, the $\mathrm{IC}_{50}$ of HepG2 cells was $80 \mu \mathrm{M}$, the $\mathrm{IC}_{50}$ of PATU-8988 cells was $300 \mu \mathrm{M}$, and the $\mathrm{IC}_{50}$ of PANC-1 cells was $120 \mu \mathrm{M}(22,27,29,31)$. The present study demonstrated that ISO decreased A549 cell viability in dose-dependent and time-dependent manner; moreover, no evident side-effects were observed on the normal cells in the 5-FU and cisplatin group; the $\mathrm{IC}_{50}$ value of the $\mathrm{A} 549$ cells was $46.81 \mu \mathrm{M}$, the $\mathrm{IC}_{50}$ of the NCI-H23 cells was $63.88 \mu \mathrm{M}$ and the $\mathrm{IC}_{50}$ of the NCI-H460 cells was $81.69 \mu \mathrm{M}$ (Fig. 1 and Table I). In addition, following treatment with ISO for $24 \mathrm{~h}$, the A549 cells exfoliated from the plate and exhibited morphology similar to apoptosis (Fig. 2A) (35). To further define the underlying mechanisms of ISO, the effects of ISO on the induction of apoptosis of the A549 cells were then investigated.

Apoptosis plays a crucial role in the process of cell proliferation, differentiation and death. Mitochondrial-dependent apoptosis is an intrinsic apoptosis, causing the release of cytochrome c, which results in caspase- 3 cleavage and ultimately leads to apoptosis (36). Bcl-2 family members are major regulators of the mitochondrial release of cytochrome $\mathrm{c}$ and can alter their conformation and form mitochondrial permeability transition pores in the mitochondrial outer membrane, releasing cytochrome $\mathrm{c}$ from the mitochondria into the cytosol $(37,38)$. In addition, previous studies have demonstrated that $\mathrm{Bcl}-2$ and Bax control programmed cell apoptosis $(39,40)$. The results of the present study revealed that ISO significantly inhibited the expression levels of Bcl-2 and increased the expression of Bax, cle-cas-3 and cle-PARP (Fig. 2D). Therefore, ISO-induced apoptosis is associated with mitochondrial-dependent pathways.

The activation of the MAPK signaling pathway plays a key role in the apoptosis of cancer cells induced by natural compounds $(41,42)$. Accumulating evidence has identified that the MAPK, STAT3 and NF- $\mathrm{KB}$ signaling pathways play important roles in cell apoptosis $(43,44)$. The results of the present study demonstrated that ISO activated the $\mathrm{p} 38$ and JNK pathways, inhibiting the ERK, STAT3 and NF- $\kappa$ B signaling pathways. In addition, the expression levels of p-STAT3 were decreased following the addition of p38 and JNK inhibitors $(10 \mu \mathrm{M})$ and were increased following the addition of an ERK inhibitor $(10 \mu \mathrm{M})$, indicating that MAPK was involved in 
the regulation of the STAT3 signaling pathway in A549 lung cancer cells (Fig. 4) (32,45-48).

A number of studies have demonstrated that some natural flavonoids appear as pro-oxidants or antioxidants depending upon the target cell $(49,50)$. The previous studies have demonstrated that ISO can upregulate ROS levels in HepG2 hepatocellular carcinoma cells to induce cell apoptosis (20). The results revealed that ISO upregulated the levels of ROS. In addition, following treatment of A549 cells with NAC the number of apoptotic cells was significantly reduced (Fig. 5B). It has been reported that ROS can induce apoptosis as a second messenger of MAPK and NF- $\kappa \mathrm{B}$ transcription factors in cancer cells. NF- $\kappa \mathrm{B}$ factor is localized in the cytoplasm and is sequestered by $\mathrm{I} \kappa \mathrm{B}$ molecules. Under some stimulating conditions, $\mathrm{I} \kappa \mathrm{B}$ undergoes ubiquitination and degradation, resulting in the translocation of $\mathrm{NF}-\kappa \mathrm{B}$ dimers into the nucleus (51-53). In the present study, it was found that ROS was involved in ISO-induced MAPK/STAT3/NF- $\kappa$ B signaling pathways as an upstream signal. Furthermore, NAC regulated the activation of the MAPK, STAT3 and NF- $\mathrm{B}$ signaling pathways (Fig. $5 \mathrm{C}$ ). The results also revealed that ISO decreased the expression levels of STAT3, p-NF- $\mathrm{B}$, $\mathrm{NF}-\kappa \mathrm{B}, \mathrm{p}-\mathrm{I} \kappa \mathrm{B}$ and $\mathrm{I} \kappa \mathrm{B}-\alpha$ in the nucleus (Fig. 5D). These results indicated that ROS activated the MAPK, STAT3 and $\mathrm{NF}-\kappa \mathrm{B}$ signaling pathways on the ISO-induced apoptosis of A549 cells.

The balance of the cell cycle is critical for maintaining intracellular stability; however, when cells are damaged, the cell cycle is arrested by various mechanisms, such as the expression of CDKs and the inhibition of cyclins (54-56). In the present study, the results of flow cytometry revealed that the number of cells in the G2/M phase increased following ISO treatment and the number of cells in the G0/G1 phase decreased. Western blot analysis revealed that $\mathrm{G} 2 / \mathrm{M}$ phase-associated protein expression levels of CDK $1 / 2$ and cyclin B1 decreased following ISO treatment. In addition, the expression levels of p21 and p27 proteins were increased. To summarize, ISO induced the cell cycle arrest of A549 lung cancer cells in the $\mathrm{G} 2 / \mathrm{M}$ phase.

In conclusion, the present study demonstrated that, ISO upregulated intracellular ROS levels, caused G2/M cell cycle arrest, and induced apoptosis by regulating the MAPK/STAT3/NF- $\kappa$ B signaling pathway in A549 human lung cancer cells. These results demonstrate the possibility of ISO as a potential treatment agent for lung cancer.

\section{Acknowledgements}

Not applicable.

\section{Funding}

The present study was funded by the Heilongjiang Farms and Land Reclamation Administration Support Project for Key Scientific Research (grant no. HKKYZD190705), the Heilongjiang Bayi Agricultural University Support Program for 'San Zong' (grant no. TDJH201905), Heilongjiang Touyan Innovation Team Program (2019HTY078), the Natural Science Foundation of Heilongjiang Province of China (QC2015121) and the Scientific Research Innovation Program for College
Graduates of Heilongjiang Bayi Agricultural University (YJSCX2019-Y69).

\section{Availability of data and materials}

The datasets used and/or analyzed during the current study are available from the corresponding author on reasonable request.

\section{Authors' contributions}

CHJ and DJZ conceived and designed the experiments. WTX and GNS wrote the manuscript and participated in the experiments. TZL and YZ assessed the cytotoxic effects of the drugs. TZ and HX performed the cell cycle and apoptotic analyses. WBZ performed the western blot analysis. YNL performed the signaling analysis. All authors read and approved the final version of the manuscript.

\section{Ethics approval and consent to participate}

Not applicable.

\section{Patient consent for publication}

Not applicable.

\section{Competing interests}

The authors declare that they have no competing interests.

\section{References}

1. Bray F, Ferlay J, Soerjomataram I, Siegel RL, Torre LA and Jemal A: Global cancer statistics 2018: GLOBOCAN estimates of incidence and mortality worldwide for 36 cancers in 185 countries. CA Cancer J Clin 68: 394-424, 2018.

2. Reinmuth N, Gröschel A, Schumann C, Sebastian M, Wiewrodt R and Reck M: Updated recommendation for treatment of metastatic non-small cell lung cancer. Pneumologie 72: 138-154, 2018 (In German).

3. Xu Z, Mei J and Tan Y: Baicalin attenuates DDP (cisplatin) resistance in lung cancer by downregulating MARK2 and p-Akt. Int J Oncol 50: 93-100, 2017.

4. Zhou Y and Ho WS: Combination of liquiritin, isoliquiritin and isoliquirigenin induce apoptotic cell death through upregulating p53 and p21 in the A549 non-small cell lung cancer cells. Oncol Rep 31: 298-304, 2014.

5. Elango R1: Athinarayanan J, Subbarayan VP, Lei DKY, Alshatwi AA: Hesperetin induces an apoptosis-triggered extrinsic pathway and a p53-independent pathway in human lung cancer H522 cells. J Asian Nat Prod Res 6: 559-569, 2018.

6. Chang JH, Lai SL, Chen WS, Hung WY, Chow JM, Hsiao M, Lee WJ and Chien MH: Quercetin suppresses the metastatic ability of lung cancer through inhibiting Snail-dependent Akt activation and Snail-independent ADAM9 expression pathways. Biochim Biophys Acta Mol Cell Res 1864: 1746-1758, 2017.

7. Zhang DX and Gutterman DD: Mitochondrial reactive oxygen species-mediated signaling in endothelial cells. Am J Physiol Heart Circ Physiol 292: H2023-H2031, 2007.

8. Zhang W and Liu HT: MAPK signal pathways in the regulation of cell proliferation in mammalian cells. Cell Res 12: 9-18, 2002.

9. Sheng W, Chen C, Dong M, Wang G, Zhou J, Song H, Li Y, Zhang $\mathrm{J}$ and Ding S: Calreticulin promotes EGF-induced EMT in pancreatic cancer cells via Integrin/EGFR-ERK/MAPK signaling pathway. Cell Death Dis 8: e3147, 2017.

10. Yu H, Lee H, Herrmann A, Buettner R and Jove R: Revisiting STAT3 signalling in cancer: New and unexpected biological functions. Nat Rev Cancer 14: 736-746, 2014. 
11. Nguyen TT, Ung TT, Li S, Lian S, Xia Y, Park SY and Do Jung Y: Metformin inhibits lithocholic acid-induced interleukin 8 upregulation in colorectal cancer cells by suppressing ROS production and NF-kB activity. Sci Rep 9: 2003, 2019.

12. Wu D, Zhou WY, Lin XT, Fang L and Xie CM: Bufalin induces apoptosis via mitochondrial ROS-mediated caspase-3 activation in HCT-116 and SW620 human colon cancer cells. Drug Chem Toxicol 42: 444-450, 2019.

13. Xu WT, Shen GN, Luo YH, Piao XJ, Wang JR, Wang H, Zhang Y, Li JQ, Feng YC, Zhang Y, et al: New naphthalene derivatives induce human lung cancer A549 cell apoptosis via ROS-mediated MAPKs, Akt, and STAT3 signaling pathways Chem Biol Interact 304: 148-157, 2019.

14. Wang JR, Shen GN, Luo YH, Piao XJ, Shen M, Liu C, Wang Y, Meng LQ, Zhang Y, Wang H, et al: The compound 2-(naphthalene-2-thio)-5,8-dimethoxy-1,4-naphthoquinone induces apoptosis via reactive oxygen species-regulated mitogen-activated protein kinase, protein kinase $\mathrm{B}$, and signal transducer and activator of transcription 3 signaling in human gastric cancer cells. Drug Dev Res 79: 295-306, 2018.

15. Xiang Y, Ye W, Huang C, Lou B, Zhang J, Yu D, Huang X, Chen B and Zhou M: Brusatol inhibits growth and induces apoptosis in pancreatic cancer cells via JNK/p38 MAPK/NF- $x$ b/Stat3/Bcl-2 signaling pathway. Biochem Biophys Res Commun 487: 820-826, 2017.

16. Peng J,Fan G,Hong Z, Chai Y and Wu Y: Preparative separation of isovitexin and isoorientin from Patrinia villosa Juss by high-speed counter-current chromatography. J Chromatogr A 1074: 111-115, 2005.

17. Prinz S, Ringl A, Huefner A, Pemp E and Kopp B 4'"-Acetylvitexin-2"-O-rhamnoside, isoorientin, orientin, and 8-methoxykaempferol-3-O-glucoside as markers for the differentiation of Crataegus monogyna and Crataegus pentagyna from Crataegus laevigata (Rosaceae). Chem Biodivers 4: 2920-2931, 2007.

18. Budzianowski J, Budzianowska A and Kromer K: Naphthalene glucoside and other phenolics from the shoot and callus cultures of Drosophyllum lusitanicum. Phytochemistry 61: 421-425, 2002.

19. Yuan L, Li X, He S, Gao C, Wang C and Shao Y: Effects of natural flavonoid isoorientin on growth performance and gut microbiota of mice. J Agric Food Chem 66: 9777-9784, 2018.

20. Yuan L, Wu Y, Ren X, Liu Q, Wang J and Liu X: Isoorientin attenuates lipopolysaccharide-induced pro-inflammatory responses through down-regulation of ROS-related MAPK/NF- $x$ B signaling pathway in BV-2 microglia. Mol Cell Biochem 386: 153-165, 2014.

21. Lee W, Ku SK and Bae JS: Vascular barrier protective effects of orientin and isoorientin in LPS-induced inflammation in vitro and in vivo. Vascul Pharmacol 62: 3-14, 2014.

22. Gundogdu G, Dodurga Y, Elmas L, Tasci SY and Karaoglan ES: Investigation of the anticancer mechanism of isoorientin isolated from Eremurus spectabilis leaves via cell cycle pathways in HT-29 human colorectal adenocarcinoma cells. Eurasian J Med 50: 168-172, 2018

23. Daniel B: Longley and D Paul Harkin, Patrick G Johnston: 5-fluorouracil: Mechanisms of Action and Clinical Strategies. Nat Rev Cancer 5: 330-338, 2003.

24. Dasari S and Tchounwou PB: Cisplatin in cancer therapy: Molecular mechanisms of action. Eur J Pharmacol 740: 364-378, 2014.

25. Rashed KN, Ćirić A, Glamočlija J, Calhelha RC, Ferreira IC and Soković M: Antimicrobial activity, growth inhibition of human tumour cell lines, and phytochemical characterization of the hydromethanolic extract obtained from Sapindus saponaria L. aerial parts. BioMed Res Int 2013: 659183, 2013

26. Li L, Henry GE and Seeram NP: Identification and bioactivities of resveratrol oligomers and flavonoids from Carex folliculata seeds. J Agric Food Chem 57: 7282-7287, 2009.

27. Yuan L, Wang J, Xiao H, Xiao C, Wang Y and Liu X: Isoorientin induces apoptosis through mitochondrial dysfunction and inhibition of PI3K/Akt signaling pathway in HepG2 cancer cells. Toxicol Appl Pharmacol 265: 83-92, 2012.

28. Czemplik M, Mierziak J, Szopa J and Kulma A: Flavonoid C-glucosides derived from flax straw extracts reduce human breast cancer cell growth in vitro and induce apoptosis. Front Pharmacol 7: 282-295, 2016.

29. Lin X, Wei J, Chen Y, He P, Lin J, Tan S, Nie J, Lu S, He M, $\mathrm{Lu} \mathrm{Z}$, et al: Isoorientin from Gypsophila elegans induces apoptosis in liver cancer cells via mitochondrial-mediated pathway. J Ethnopharmacol 187: 187-194, 2016.
30. Vadde R, Radhakrishnan S, Reddivari L and Vanamala JK: Triphala extract suppresses proliferation and induces apoptosis in human colon cancer stem cells via suppressing c-Myc/Cyclin D1 and elevation of Bax/Bcl-2 ratio. BioMed Res Int 2015: 649263 , 2015.

31. Ye T, Su J, Huang C, Yu D, Dai S, Huang X, Chen B and Zhou M: Isoorientin induces apoptosis, decreases invasiveness, and downregulates VEGF secretion by activating AMPK signaling in pancreatic cancer cells. OncoTargets Ther 9: 7481-7492, 2016.

32. Yuan L, Wang J, Xiao H, Wu W, Wang Y and Liu X: MAPK signaling pathways regulate mitochondrial-mediated apoptosis induced by isoorientin in human hepatoblastoma cancer cells Food Chem Toxicol 53: 62-68, 2013

33. Yuan L, Wang Y, Wang J, Xiao H and Liu X: Additive effect of zinc oxide nanoparticles and isoorientin on apoptosis in human hepatoma cell line. Toxicol Lett 225: 294-304, 2014.

34. Yuan L, Wei S, Wang J and Liu X: Isoorientin induces apoptosis and autophagy simultaneously by reactive oxygen species (ROS)-related p53, PI3K/Akt, JNK, and p38 signaling pathways in HepG2 cancer cells. J Agric Food Chem 62: 5390-5400, 2014

35. Na D, Song Y, Jiang CG, Sun Z, Xu YY, Wang ZN, Zhao ZZ and $\mathrm{Xu} \mathrm{HM}$ : Induction of apoptosis in human peritoneal mesothelial cells by gastric cancer cell supernatant promotes peritoneal carcinomatosis. Tumour Biol 35: 8301-8307, 2014.

36. Morales-Cruz M, Figueroa CM, González-Robles T, Delgado Y, Molina A, Méndez J, Morales M and Griebenow K: Activation of caspase-dependent apoptosis by intracellular delivery of Cytochrome c-based nanoparticles. J Nanobiotechnology 12: 33 , 2014.

37. Zhang M, Zheng J, Nussinov R and Ma B: Release of cytochrome $\mathrm{c}$ from bax pores at the mitochondrial membrane. Sci Rep 7: 2635, 2017.

38. Shimizu S, Narita M, Tsujimoto Y and Tsujimoto Y: Bcl-2 family proteins regulate the release of apoptogenic cytochrome $\mathrm{c}$ by the mitochondrial channel VDAC. Nature 399: 483-487, 1999.

39. Oltvai ZN, Milliman CL and Korsmeyer SJ: Bcl-2 heterodimerizes in vivo with a conserved homolog, Bax, that accelerates programmed cell death. Cell 74: 609-619, 1993.

40. Korsmeyer SJ: BCL-2 gene family and the regulation of programmed cell death. Cancer Res 59 (Suppl): 1693s-1700s, 1999.

41. Park SG, Kim SH, Kim KY, Yu SN, Choi HD, Kim YW, Nam HW, Seo YK and Ahn SC: Toyocamycin induces apoptosis via the crosstalk between reactive oxygen species and p38/ERK MAPKs signaling pathway in human prostate cancer PC-3 cells Pharmacol Rep 69: 90-96, 2017.

42. Chen $X$ and Chen J: miR-3188 Regulates Cell Proliferation, Apoptosis, and Migration in Breast Cancer by Targeting TUSC5 and Regulating the p38 MAPK Signaling Pathway. Oncol Res 26: 363-372, 2018

43. Zou F, Mao R, Yang L, Lin S, Lei K, Zheng Y, Ding Y, Zhang P, Cai G, Liang X, et al: Targeted deletion of miR-139-5p activates MAPK, NF- $\mathrm{KB}$ and STAT3 signaling and promotes intestinal inflammation and colorectal cancer. FEBS J 283: 1438-1452, 2016.

44. Meng LQ, Liu C, Luo YH, Piao XJ, Wang Y, Zhang Y, Wang JR, Wang H, Xu WT, Liu Y, et al: Quinalizarin exerts an anti-tumour effect on lung cancer A549 cells by modulating the Akt, MAPK, STAT3 and p53 signalling pathways. Mol Med Rep 17: 2626-2634, 2018.

45. Hwang HS, Park SJ, Lee MH and Kim HA: MicroRNA-365 regulates IL-1 $\beta$-induced catabolic factor expression by targeting HIF-2 $\alpha$ in primary chondrocytes. Sci Rep 7: 17889, 2017.

46. Fu Y, O'Connor LM, Shepherd TG and Nachtigal MW: The p38 MAPK inhibitor, PD169316, inhibits transforming growth factor beta-induced Smad signaling in human ovarian cancer cells. Biochem Biophys Res Commun 310: 391-397, 2003.

47. Hour MJ, Lee KT, Wu YC, Wu CY, You BJ, Chen TL and Lee HZ: A novel antitubulin agent, DPQZ, induces cell apoptosis in human oral cancer cells through Ras/Raf inhibition and MAP kinases activation. Arch Toxicol 87: 835-846, 2013.

48. Ito K, Matsuzaki M, Sasahara T, Shin M and Yayama K: Orthovanadate-Induced Vasoconstriction of Rat Mesenteric Arteries Is Mediated by Rho Kinase-Dependent Inhibition of Myosin Light Chain Phosphatase. Biol Pharm Bull 38: 1809-1816, 2015.

49. Yang S, Zhang H, Yang X, Zhu Y and Zhang M: Evaluation of antioxidative and antitumor activities of extracted flavonoids from Pink Lady apples in human colon and breast cancer cell lines. Food Funct 6: 3789-3798, 2015. 
50. Wang Y, Qian J, Cao J, Wang D, Liu C, Yang R, Li X and Sun C: Antioxidant capacity, anticancer ability and flavonoids composition of 35 citrus (Citrus reticulata Blanco) varieties. Molecules 22: E1114, 2017.

51. Zuo D, Zhou Z, Wang H, Zhang T, Zang J, Yin F, Sun W, Chen J, Duan L, Xu J, et al: Alternol, a natural compound, exerts an anti-tumour effect on osteosarcoma by modulating of STAT3 and ROS/MAPK signalling pathways. J Cell Mol Med 21: 208-221, 2017.

52. Meng LQ, Wang Y, Luo YH, Piao XJ, Liu C, Wang Y, Zhang Y, Wang JR, Wang H, Xu WT, et al: Quinalizarin induces apoptosis through reactive oxygen species (ROS)-mediated mitogen-activated protein kinase (MAPK) and signal transducer and activator of transcription 3 (STAT3) signaling pathways in colorectal cancer cells. Med Sci Monit 24: 3710-3719, 2018.

53. Liu C, Shen GN, Luo YH, Piao XJ, Jiang XY, Meng LQ, Wang Y, Zhang Y, Wang JR, Wang H, et al: Novel 1,4-naphthoquinone derivatives induce apoptosis via ROS-mediated p38/MAPK Akt and STAT3 signaling in human hepatoma Hep3B cells. Int J Biochem Cell Biol 96: 9-19, 2018.
54. Cheng CW, Leong KW, Ng YM, Kwong YL and Tse E: The peptidyl-prolyl isomerase PIN1 relieves cyclin-dependent kinase 2 (CDK2) inhibition by the CDK inhibitor p27. J Biol Chem 292: 21431-21441, 2017.

55. Bonelli P, Tuccillo FM, Borrelli A, Schiattarella A and Buonaguro FM: CDK/CCN and CDKI alterations for cancer prognosis and therapeutic predictivity. BioMed Res Int 2014: 361020, 2014.

56. Sarita Rajender P, Ramasree D, Bhargavi K, Vasavi M and Uma V: Selective inhibition of proteins regulating CDK/cyclin complexes: Strategy against cancer - a review. J Recept Signal Transduct Res 30: 206-213, 2010. 